\title{
Do Political Connections Affect Stock Price Crash Risk-Based on Empirical Evidence from China's Capital Market
}

\author{
Keping Wu \\ School of Business Administration, Chaohu University, Hefei, China
}

\begin{abstract}
:
Using data from China's capital market, the intrinsic relationship between political connections and crash risk is tested. Empirical research find that political connections and crash risk are significantly negative correlated after controlling for the influence of relevant factors; a company with higher proportion of major shareholders, and in company with lower degree of marketization, the negative correlation between political connections and crash risk is more significant; political links of non-foreign funded enterprises is more effective than political connections of foreign funded enterprises in reducing crash risk. The research results indicate that we should exert the positive influence of political connections, reduce the shareholding ratio of major shareholders, accelerate the process of marketization, strengthen corporate governance of non-foreign funded enterprise, and can reduce stock price crash risk, therefore, it will help steady operation of China's capital market.
\end{abstract}

Keywords: Political Connections, Stock Price Crash Risk, Capital Market, Mechanism, Institutional Background; Foreign-Funded Enterprises.

\section{INTRODUCTION}

The collapse of stock price in capital market badly damages economic interests of shareholders and causes more serious economic losses to small and medium shareholders. It will affect investors' confidence in the capital market and damage smooth operation of the capital market. Furthermore, it may trigger a financial crisis. Since china established securities market in the 1990s in the last century, it has experienced many stock price surges and plunges and investors suffered heavy losses, which virtually hindered the healthy development of financial market. Therefore, this paper analyzes its impact on crash risk from the perspective of political connections, and has certain practical significance for how to reduce crash risk, promote the smooth operation and development of financial market. 
The contributions of this paper are mainly reflected in following three ways. Firstly, the extant research rarely explores the influence of political connections on crash risk from the perspective of foreign funded enterprises, which provides a new research perspective for the factors which affects crash risk. Secondly, this paper enriches the research in the field of crash risk. Finally, research conclusion has certain enlightening significance for how to reduce crash risk.

This paper is organized as follows. Section 2 reviews the related literature and develops the hypothesis. Section 3 describes the sample, variable and model are presented in section3. Section 4 reports empirical analyses and research results. Section 5 conducts robustness test. Section 6 additional tests. Finally, we draw the conclusions.

\section{LITERATURE REVIEW AND RESEARCH HYPOTHESES}

The research on political links at home and abroad is relatively rich, and the summary is as follows:

\subsection{Political Links and Accounting Earnings Quality}

Prior research find political links impairs the quality of corporate accounting information. The reason is that the quality of accounting earnings is lower in companies with political connections [1]. In addition, analysts' forecast errors are highe1r in politically connected companies [2]. Furthermore, the probability of financial report disclosure errors of politicallylinked companies is higher during financial crisis. In all, political connection of private enterprises may reduce the quality of accounting earnings [3].

\subsection{Political Links and Corporate Value}

The effect of political links on firm value is mainly reflected in the following three aspects, one is a positive impact, the other is a negative impact, and the third is a mixed impact.

\subsubsection{Political connections increase corporate value}

Research find that political links can enhance the value of enterprises to a certain extent [4-7]. In addition, if the government interferes more severely, political connections can help to enhance the value of company [8], which shows that the establishment of political connection by the company has a positive effect. 


\subsubsection{Political connections reduce corporate value}

Existing research find that political connections reduce firm value [9-13], which indicates that political links has a negative impact on them.

\subsubsection{The impact of political links on firm value is uncertain}

Research find political links are established by the chairman of the board can increase corporate performance, while the political connections established by corporate managers can damage corporate performance [14]. [15] Believe that the political connections of core executives of a company can improve corporate performance to a certain extent, while the political connections established by non-core executives have a negative effect on firm performance. In addition, if independent directors establish political connections, they will have less impact on the business earnings of the firm. On the other hand, political connections of government officials will reduce corporate performance. However, if the political connections belong to the representative committee category, it will have a positive influence on firm profits [16].Therefore, the effect of political connections on corporate value is uncertain.

\subsection{Political Connection and Enterprise Resource Allocation}

\subsubsection{The influence of political links on investment efficiency}

Research find that private enterprises can obtain government support for establishing political connections, so that they can easily enter government-regulated industry and broaden the investment channels of private enterprises [17].In addition, political connections can help companies reduce the cost of coordination with government agencies, and therefore can improve investment efficiency [18].However, political links of private firms may easily lead to overinvestment, which has a negative influence on investment efficiency [19]. Therefore, we can draw a conclusion that the effect of political link on investment efficiency is uncertain.

\subsubsection{The influence of political links on financing costs}

Extant research find the amount of bank loans will increase after companies establish political connections [20]. In addition, private enterprises are subject to relatively less financing constraints for establishing political connections, so the maturity of bank loan will be extended [21]. Furthermore, from the perspective of equity financing, political links can also help reduce 
the cost of equity financing [22]. At the same time, if companies establish political connections, they can easily obtain government subsidies and tax incentives [11,23].Therefore, political connections can facilitate corporate financing and other conveniences.

\subsection{Political Links and Crash Risk}

Regarding the effect of political connections on crash risk, there are mainly two views. One view is that political connections increase crash risk [24-25]; another view is that political connections reduce crash risk [26-27]. In short, the research conclusions are uncertain. In addition, the existing literature lacks a discussion of the influence of political links on crash risk from the perspective of foreign funded companies. Therefore, this paper will further explore the mechanism of political links on crash risk and explore the effect of political connections on crash risk from the perspective of foreign funded companies.

\subsection{Hypothesis Development}

Exiting research believe that political links have the function of supporting hands [5,28,29]. When enterprises encounter difficulties, the government will provide corresponding assistance [30]. Find that corporate political donations can help improve the company's future stock returns. In addition, companies with political connections have higher stock returns [4]. This means that compared with those companies that have not established political connections, crash risk will be greatly reduced. From another perspective, firms that have established political connections usually have a good corporate image. At this time, the probability of hiding bad information will decrease in company. Based on this, this paper proposes hypothesis 1:

H1: ceteris paribus, political connection has a significant negative correlation with crash risk.

\section{DATA, VARIABLES, AND MODELS}

\subsection{Sample and Data}

In view of the natural universality of state-owned enterprises' political connections in China, it is of little significance to conduct the research. In addition, the availability and completeness of data are also considered. Therefore, this paper uses the data of private firms during the period 2000-2012, excluding the data of ST and PT companies, the missing data and the data of financial and insurance companies are deleted. The data in this paper comes from CSMAR's 

levels. Finally, we obtain an effective sample size of 8163.

\subsection{Variable}

\subsubsection{Stock price crash risk}

Based on existing research [31-32], this paper uses NCSKEW and DUVOL to estimate crash risk. Details as follows:

Firstly, this paper use the weekly stock return data of the financial market to estimate model (1):

$$
\mathrm{R}_{\mathrm{i}, \mathrm{t}}=\propto_{\mathrm{i}}+\beta_{1} \mathrm{R}_{\mathrm{m}, \mathrm{t}-2}+\beta_{2} \mathrm{R}_{\mathrm{m}, \mathrm{t}-1}+\beta_{3} \mathrm{R}_{\mathrm{m}, \mathrm{t}}+\beta_{4} \mathrm{R}_{\mathrm{m}, \mathrm{t}+1}+\beta_{5} \mathrm{R}_{\mathrm{m}, \mathrm{t}+2}+\varepsilon_{\mathrm{i}, \mathrm{t}}
$$

In model (1), $R_{i, t}$ represents the stock return of stock $i$ in week $t$, and $R_{m}$ is the weighted average market return rate in week t. The specific weekly stock return is $i_{i, t}=\left(1+\varepsilon_{i, t}\right)$, where $\varepsilon_{i, t}$ is the residual item of the regression of model (1).

Second, based on $\mathrm{W}_{\mathrm{i}, \mathrm{t}}$, this paper produce two variables to calculate crash risk, details as follows:

(1) Negative coefficient of return skewness (NCSKEW)

$$
\operatorname{NCSKEW~}_{\mathrm{i}, \mathrm{t}}=-\left[\mathrm{n}(\mathrm{n}-1)^{3 / 2} \sum \mathrm{W}_{\mathrm{i}, \mathrm{t}}^{3}\right] /\left[(\mathrm{n}-1)(\mathrm{n}-2)\left(\sum \mathrm{W}_{\mathrm{i}, \mathrm{t}}^{2}\right)^{3 / 2}\right]
$$

In equation (2), $\mathrm{n}$ is the annual trading week of stock $\mathrm{i}$ in year $\mathrm{t}$.

(2) Down-to-up of volatility(DUVOL)

$$
\operatorname{DUVOL}_{\mathrm{i}, \mathrm{t}}=\log \left\{\left[\left(\mathrm{n}_{\mathrm{u}}-1\right) \sum_{\text {DOWN }} \mathrm{W}_{\mathrm{i}, \mathrm{t}}^{2}\right] /\left[\left(\mathrm{n}_{\mathrm{d}}-1\right) \sum_{\mathrm{UP}} \mathrm{W}_{\mathrm{i}, \mathrm{t}}^{2}\right]\right\}
$$


In equation (3), $\mathrm{n}_{\mathrm{u}}$ and $\mathrm{n}_{\mathrm{d}}$ are the number of up and down weeks for stock $\mathrm{i}$ in year $\mathrm{t}$, respectively. A higher value of NCSKEW or DUVOL represents greater crash risk.

\subsubsection{Political connection}

Following prior research [33], this paper defines a corporate whose chairman or general manager is a current or former government official, NPC deputies, or CPPCC member as a politically linked company. If the company has political connections, $\mathrm{PC}$ (political connections) is defined as 1 , otherwise 0 .

\subsubsection{Model}

To test the relationship between political links and crash risk, this paper constructs following model:

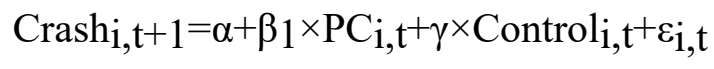

In model (4), Crash is calculated by NCSKEW and DUVOL. Refer to previous literature [31,32,34], we control Ret, Sigma, Turnover, Size, Lev, Mb, etc.

\section{IV.ANALYSIS OF EMPIRICAL AND RESULTS}

\subsection{Descriptive Statistics}

Table I lists descriptive statistical results of each variable. The mean of NCSKEW and DUVOL are -0.208 and -0.151 , respectively, and STDs (standard deviations) are 0.881 and 0.712 , respectively, which shows that there is a certain difference between two variables that calculate crash risk. The mean of PC is 0.243 , indicating that enterprises have a higher proportion of establishing political connections.

\subsection{Univariate Analysis}

Table II lists a univariate analysis about crash risk. This paper finds that political connection corporations have a lower crash risk than that of non-political connection firms. For example, the mean of NCSKEW in political connection firms is -0.311 and less than the mean in non-political connection firms by 0.137 . The difference is significant at $1 \%$ level. In addition, the mean test on DUVOL has similar results. Therefore, the crash risk of political connection 
TABLE I. Descriptive statistics of variables

\begin{tabular}{|l|l|l|l|l|l|l|l|}
\hline VARIABLE & MEAN & STD.DEV & MIN & P25 & P50 & P75 & MAX \\
\hline NCSKEW & -0.207 & 0.881 & -2.905 & -0.754 & -0.189 & 0.354 & 2.090 \\
\hline DUVOL & -0.151 & 0.712 & -2.005 & -0.627 & -0.149 & 0.327 & 1.674 \\
\hline PC & 0.243 & 0.429 & 0.000 & 0.000 & 0.000 & 0.000 & 1.000 \\
\hline TURNOVER & -0.096 & 0.412 & -2.293 & -0.267 & -0.048 & 0.099 & 1.118 \\
\hline RET & -0.145 & 0.594 & -1.748 & -0.492 & -0.165 & 0.203 & 1.610 \\
\hline SIGMA & 0.046 & 0.017 & 0.019 & 0.033 & 0.044 & 0.057 & 0.107 \\
\hline SIZE & 21.739 & 1.216 & 19.664 & 20.874 & 21.547 & 22.379 & 26.190 \\
\hline LEV & 0.484 & 0.189 & 0.074 & 0.345 & 0.494 & 0.625 & 0.914 \\
\hline ROA & 0.035 & 0.057 & -0.289 & 0.014 & 0.035 & 0.059 & 0.182 \\
\hline MB & 1.694 & 0.903 & 0.893 & 1.148 & 1.385 & 1.875 & 7.184 \\
\hline
\end{tabular}

TABLE II. Univariate analysis of crash risk

\begin{tabular}{|l|l|l|l|l|}
\hline & PC=0 & PC=1 & DIFFERENCE & T-VALUE \\
\hline \multirow{2}{*}{ NCSKEW } & -0.174 & -0.311 & $0.137^{* * * *}$ & 6.44 \\
& $(0.011)$ & $(0.018)$ & $(0.021)$ & \\
\hline \multirow{2}{*}{ DUVOL } & -0.128 & -0.225 & $0.097^{* * * *}$ & 5.65 \\
& $(0.009)$ & $(0.014)$ & $(0.017)$ & \\
\hline
\end{tabular}

4.3 Correlation Analysis

TABLE III. Correlation analysis

\begin{tabular}{|l|l|l|l|l|l|l|l|l|l|l|}
\hline & $\begin{array}{l}\text { NCSK } \\
\text { EW }\end{array}$ & $\begin{array}{l}\text { DUV } \\
\text { OL }\end{array}$ & PC & $\begin{array}{l}\text { TURNO } \\
\text { VER }\end{array}$ & RET & $\begin{array}{l}\text { SIG } \\
\text { MA }\end{array}$ & SIZE & LEV & ROA & MB \\
\hline $\begin{array}{l}\text { NCSKE } \\
\text { W }\end{array}$ & 1 & $0.930^{* * * *}$ & $-0.063^{* * * *}$ & $-0.099^{* * * *}$ & $-0.577^{* * * *}$ & $-0.167^{* * * *}$ & $-0.057^{* * * *}$ & -0.009 & $-0.110^{* * * *}$ & $-0.160^{* * * *}$ \\
\hline DUVOL & $0.917^{* * *}$ & 1 & $-0.059^{* * *}$ & $-0.102^{* * * *}$ & $-0.673^{* * *}$ & $-0.180^{* * * *}$ & $-0.056^{* * *}$ & -0.006 & $-0.146^{* * * *}$ & $-0.197^{* * *}$ \\
\hline PC & $-0.066^{* * *}$ & $-0.058^{* * *}$ & 1 & $-0.165^{* * *}$ & -0.012 & $0.073^{* * *}$ & $0.158^{* * *}$ & 0.013 & $0.088^{* * * *}$ & $0.050^{* * * *}$ \\
\hline
\end{tabular}


Article History: Received: 12 May 2021 Revised: 25 June 2021 Accepted: 22 July 2021 Publication: 31 August 2021

\begin{tabular}{|l|l|l|l|l|l|l|l|l|l|l|}
\hline $\begin{array}{l}\text { TURNO } \\
\text { VER }\end{array}$ & $-0.078^{* * *}$ & $-0.085^{* * *}$ & $-0.165^{* * *}$ & 1 & $0.028^{* * *}$ & $0.237^{* * *}$ & -0.004 & $0.089^{* * *}$ & $-0.074^{* * *}$ & $0.058^{* * *}$ \\
\hline RET & $-0.547^{* * *}$ & $-0.676^{* * *}$ & -0.003 & $0.041^{* * *}$ & 1 & $0.043^{* * *}$ & 0.011 & -0.006 & $0.200^{* * *}$ & $0.169^{* * *}$ \\
\hline SIGMA & $-0.175^{* * *}$ & $-0.190^{* * *}$ & $0.044^{* * *}$ & $0.238^{* * *}$ & $0.088^{* * *}$ & 1 & $-0.072^{* * *}$ & $0.105^{* * *}$ & -0.009 & $0.354^{* * *}$ \\
\hline SIZE & $-0.047^{* * *}$ & $-0.046^{* * *}$ & $0.171^{* * *}$ & 0.007 & -0.000 & $-0.091^{* * *}$ & 1 & $0.376^{* * *}$ & $0.117^{* * *}$ & $-0.369^{* * *}$ \\
\hline LEV & -0.013 & -0.008 & 0.014 & $0.127^{* * *}$ & -0.001 & $0.107^{* * *}$ & $0.369^{* * *}$ & 1 & $-0.377^{* * *}$ & $-0.249^{* * *}$ \\
\hline ROA & $-0.118^{* * *}$ & $-0.154^{* * *}$ & $0.089^{* * *}$ & $-0.078^{* * *}$ & $0.194^{* * *}$ & $-0.035^{* * *}$ & $0.144^{* * *}$ & $-0.348^{* * *}$ & 1 & $0.265^{* * *}$ \\
\hline MB & $-0.138^{* * *}$ & $-0.179^{* * *}$ & $0.040^{* * *}$ & $0.061^{* * *}$ & $0.201^{* * * *}$ & $0.328^{* * *}$ & $-0.295^{* * *}$ & $-0.218^{* * *}$ & $0.174^{* * *}$ & 1 \\
\hline
\end{tabular}

Table III presents the correlation coefficient between NCSKEW and DUVOL is 0.916, and it is pronounced at one percent level, suggesting that two variables for measuring crash risk are consistent. PC (political connections) has a negative correlation with NCSKEW and DUVOL, which is in line with the assumption of hypothesis 1 , but regression analysis and verification need to be carried out after controlling the relevant factors. Moreover, the conclusions drawn from the Spearman correlation coefficient in the upper right of table III are basically the same.

\subsection{Empirical Results and Analysis}

\subsubsection{Poitical link and crash risk}

Table IV presents the empirical results of model (1). As can be seen from column 1 of Table IV, using NCSKEW to measure crash risk, the regression coefficient of PC is -0.236 , and T value is -6.47 , which is pronounced at one percent level, compared with firms that have not established political links, the establishment of political links by firms may reduce crash risk, so it verifies the validity of hypothesis 1 . Furthermore, DUVOL is used to calculate crash risk, and the conclusions are basically unchanged.

TABLE IV. The impact of political connections on stock price crash risk

\begin{tabular}{|l|l|l|}
\hline \multirow{2}{*}{ VARIABLE } & $(\mathbf{1})$ & $(\mathbf{2})$ \\
\cline { 2 - 3 } & NCSKEW $_{\mathrm{t}+1}$ & DUVOL $_{\mathrm{t}+1}$ \\
\hline $\mathrm{PC}_{\mathrm{t}}$ & $-0.236^{* * *}$ & $-0.202^{* * *}$ \\
\hline
\end{tabular}


Article History: Received: 12 May 2021 Revised: 25 June 2021 Accepted: 22 July 2021 Publication: 31 August 2021

\begin{tabular}{|c|c|c|}
\hline & $(-6.47)$ & $(-6.81)$ \\
\hline \multirow[t]{2}{*}{ NCSKEW $_{\mathrm{t}}$} & $-0.069^{* * * *}$ & \\
\hline & $(-4.38)$ & \\
\hline \multirow[t]{2}{*}{$\mathrm{DUVOL}_{\mathrm{t}}$} & & $-0.045^{* * *}$ \\
\hline & & $(-2.60)$ \\
\hline \multirow[t]{2}{*}{$\mathrm{RET}_{\mathrm{t}}$} & $0.084^{* * * *}$ & $0.095^{* * * *}$ \\
\hline & $(4.17)$ & $(5.02)$ \\
\hline \multirow[t]{2}{*}{ SIGMA $_{t}$} & $-1.763^{* *}$ & $-1.479^{* * *}$ \\
\hline & $(-2.46)$ & $(-2.54)$ \\
\hline \multirow[t]{2}{*}{ TURNOVER $_{\mathrm{t}}$} & $0.116^{* * * *}$ & $0.097^{* * *}$ \\
\hline & $(4.12)$ & $(4.32)$ \\
\hline \multirow[t]{2}{*}{$\mathrm{SIZE}_{\mathrm{t}}$} & $0.122^{* * * *}$ & $0.152^{* * * *}$ \\
\hline & $(4.88)$ & $(7.58)$ \\
\hline \multirow[t]{2}{*}{$\mathrm{LEV}_{\mathrm{t}}$} & $-0.554^{* * *}$ & $-0.480^{* * * *}$ \\
\hline & $(-4.06)$ & $(-4.42)$ \\
\hline \multirow[t]{2}{*}{$\mathrm{ROA}_{\mathrm{t}}$} & 0.227 & 0.161 \\
\hline & $(0.70)$ & $(0.61)$ \\
\hline \multirow[t]{2}{*}{$\mathrm{MB}_{\mathrm{t}}$} & $0.146^{* * * *}$ & $0.119^{\text {***** }}$ \\
\hline & $(9.21)$ & $(9.42)$ \\
\hline \multirow[t]{2}{*}{ CONSTANT } & $-2.742^{\text {*** }}$ & 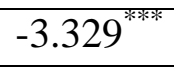 \\
\hline & $(-5.33)$ & $(-8.03)$ \\
\hline $\begin{array}{ll}\text { YEAR } & \text { FIXED } \\
\text { EFFECTS } & \end{array}$ & yes & yes \\
\hline $\begin{array}{ll}\text { FIRM } & \text { FIXED } \\
\text { EFFECTS } & \end{array}$ & yes & yes \\
\hline OBS & 8163 & 8163 \\
\hline $\mathrm{R}^{2}$ (WITHIN) & 0.044 & 0.048 \\
\hline
\end{tabular}

$t$ statistics in parentheses

${ }^{*} p<0.1,{ }^{* *} p<0.05,{ }^{* * *} p<0.01$

\subsubsection{Endogeneity}

In view of the possible endogenous problems of political links, following [10], we choose the registered place of company as the instrumental variable of political connection and use the Heckman self-selection model to test. Therefore, we construct a probity model (5), and measure IMR as model (4) control variables to solve endogeneity problems. 
In model (5), PC indicates political connections. Registration represents the place of firm registration. The explanation of other variables is the same as model (4). Table $\mathrm{V}$ shows test results of endogeneity. The regression results show that the research conclusion is still valid after addressing the endogeneity issues.

TABLE V. Test of endogeneity

\begin{tabular}{|c|c|c|}
\hline \multicolumn{3}{|c|}{ PANEL A FIRST STAGE OF HECKMAN MODEL } \\
\hline $\mathrm{PC}$ & $\mathrm{df} / \mathrm{dx}$ & $\mathrm{P}>|\mathrm{z}|$ \\
\hline REGISTRATION & 0.039 & 0.000 \\
\hline SIZE & 0.069 & 0.00 \\
\hline LEV & -0.058 & 0.038 \\
\hline ROA & 0.322 & 0.001 \\
\hline MB & 0.041 & 0.000 \\
\hline OBS & & 8163 \\
\hline PSEUDO-R ${ }^{2}$ & & 0.038 \\
\hline \multicolumn{3}{|c|}{ PANEL B REGRESSION RESULTS WITH HACKMAN MODEL } \\
\hline & NCSKEW $_{t+1}$ & DUVOL $_{t+1}$ \\
\hline \multirow[t]{2}{*}{ NCSKEW $_{t}$} & $-0.072^{* * * *}$ & \\
\hline & $(-4.51)$ & \\
\hline \multirow[t]{2}{*}{$\mathrm{DUVOL}_{\mathrm{t}}$} & & $-0.048^{* * *}$ \\
\hline & & $(-2.74)$ \\
\hline \multirow[t]{2}{*}{$\mathrm{PC}_{\mathrm{t}}$} & $-0.229^{\text {******4}}$ & $-0.196^{* * * 3}$ \\
\hline & $(-6.33)$ & $(-6.60)$ \\
\hline \multirow[t]{2}{*}{ TURNOVER $_{\mathrm{t}}$} & $0.117^{* * * *}$ & $0.098^{* * * *}$ \\
\hline & $(4.17)$ & $(4.37)$ \\
\hline \multirow[t]{2}{*}{$\mathrm{RET}_{\mathrm{t}}$} & $0.084^{* * * *}$ & $0.095^{* * * *}$ \\
\hline & $(4.15)$ & $(4.98)$ \\
\hline \multirow[t]{2}{*}{ SIGMA $_{t}$} & $-1.836^{* * *}$ & $-1.505^{* * 4}$ \\
\hline & $(-2.56)$ & $(-2.57)$ \\
\hline \multirow[t]{2}{*}{$\mathrm{SIZE}_{\mathrm{t}}$} & $0.523^{* * *}$ & $0.493^{* * * *}$ \\
\hline & $(2.92)$ & $(3.30)$ \\
\hline \multirow[t]{2}{*}{$\mathrm{LEV}_{\mathrm{t}}$} & $-0.892^{* * * *}$ & $-0.767^{* * *}$ \\
\hline & $(-4.47)$ & $(-4.70)$ \\
\hline
\end{tabular}


Article History: Received: 12 May 2021 Revised: 25 June 2021 Accepted: 22 July 2021 Publication: 31 August 2021

\begin{tabular}{|l|l|l|}
\hline ROA $_{\mathrm{t}}$ & $2.204^{* * *}$ & $1.850^{* * *}$ \\
\hline & $(2.38)$ & $(2.42)$ \\
\hline $\mathrm{MB}_{\mathrm{t}}$ & $0.382^{* * * *}$ & $0.320^{* * * *}$ \\
\hline & $(3.67)$ & $(3.68)$ \\
\hline $\mathrm{IMR}_{\mathrm{t}}$ & $3.218^{* * *}$ & $2.941^{* * *}$ \\
\hline & $(2.50)$ & $(2.74)$ \\
\hline CONSTANT & $-14.886^{* * *}$ & $-13.666^{* * *}$ \\
\hline & $(-2.76)$ & $(-3.04)$ \\
\hline OBS & 8163 & 8163 \\
\hline $\mathrm{R}^{2}$ (WITHIN) & 0.045 & 0.050 \\
\hline
\end{tabular}

On the other hand, we use PSM to amend sample selection bias, specifically, nearest neighbor matching (NNM), radius matching (RM) and kernel matching (KM) are used, and test results are present in Table VI. Table VI shows that the results of NNM, RM, and KM are basically the same, which further verifies the validity of hypothesis 1 .

TABLE VI. The result of PSM

\begin{tabular}{|l|l|l|l|l|l|}
\hline $\begin{array}{l}\text { VARIAB } \\
\text { LE }\end{array}$ & $\begin{array}{l}\text { MATCH } \\
\text { TYPE }\end{array}$ & $\begin{array}{l}\text { TREAT } \\
\text { GROU } \\
\text { P }\end{array}$ & $\begin{array}{l}\text { CONTR } \\
\text { OL } \\
\text { GROUP }\end{array}$ & ATT & T-VALUE \\
\hline NCSKEW & $\begin{array}{l}\text { Nearest } \\
\text { Neighbor } \\
\text { match(1:1) }\end{array}$ & -0.351 & -0.274 & -0.077 & -2.38 \\
\hline DUVOL & $\begin{array}{l}\text { Nearest } \\
\text { Neighbor } \\
\text { match(1:1) }\end{array}$ & -0.249 & -0.190 & -0.059 & -2.30 \\
\hline NCSKEW & $\begin{array}{l}\text { Radius } \\
\text { match(0.01) }\end{array}$ & -0.351 & -0.252 & -0.099 & -4.16 \\
\hline NCSKEW & $\begin{array}{l}\text { Radius match } \\
(0.01)\end{array}$ & -0.250 & -0.183 & -0.067 & -3.52 \\
\hline DUVOL & Kernel match & -0.351 & -0.248 & -0.103 & -4.41 \\
\hline
\end{tabular}

\subsubsection{Mechanisms}

Existing research find companies that have established political connections will disclose 
negative information in a timely manner, so as to obtain government subsidies [26]. Furthermore, in order to be promoted, Officials of politically connected companies need to establish a good image in the outside world, so as to avoid the negative impact of the disclosure of negative information on the promotion of officials in the future, therefore, politically connected companies will also disclose negative information as soon as possible. As a result, the firm's crash risk will further decrease.

To test above prediction, referring to prior research [35], this paper divides the sample into two groups (good news and bad news) based on the earnings per share (EPS) predicted by analysts. Table VII presents the empirical test results, which indicates the coefficients on the PC variable are negative and pronounced in the bad news group with lower EPS. The coefficients on the PC variable are not pronounced in good news group. It shows that business managers report negative information more timely facing with lower EPS, resulting in the lower stock price crash risk.

TABLE VII. Mechanism test

\begin{tabular}{|c|c|c|c|c|}
\hline \multirow{3}{*}{ VARIABLE } & \multicolumn{2}{|l|}{ BAD NEWS } & \multicolumn{2}{|c|}{ GOOD NEWS } \\
\hline & (1) & (2) & (3) & (4) \\
\hline & $\operatorname{NCSKEW}_{t+1}$ & DUVOL $_{t+1}$ & NCSKEW $_{t+1}$ & DUVOL $_{t+1}$ \\
\hline \multirow[t]{2}{*}{$\mathrm{PC}_{\mathrm{t}}$} & $-0.426^{* *}$ & $-0.405^{* *}$ & -0.100 & -0.180 \\
\hline & $(-2.40)$ & $(-2.55)$ & $(-0.55)$ & $(-1.04)$ \\
\hline \multirow[t]{2}{*}{$\mathrm{NCSKEW}_{\mathrm{t}}$} & $-0.116^{* *}$ & & $-0.197^{*}$ & \\
\hline & $(-2.17)$ & & $(-1.79)$ & \\
\hline \multirow[t]{2}{*}{ DUVOL $_{t}$} & & -0.064 & & -0.169 \\
\hline & & $(-1.13)$ & & $(-1.59)$ \\
\hline \multirow[t]{2}{*}{$\mathrm{RET}_{\mathrm{t}}$} & 0.054 & 0.062 & 0.101 & 0.140 \\
\hline & $(0.75)$ & (0.94) & $(1.11)$ & $(1.59)$ \\
\hline \multirow[t]{2}{*}{ SIGMA $_{t}$} & -0.950 & -0.283 & -3.659 & -2.996 \\
\hline & $(-0.38)$ & $(-0.13)$ & $(-0.76)$ & $(-0.69)$ \\
\hline \multirow[t]{2}{*}{ TURNOVER $_{\mathrm{t}}$} & $0.222^{*}$ & 0.118 & 0.116 & 0.174 \\
\hline & $(1.95)$ & $(1.17)$ & $(0.70)$ & $(1.22)$ \\
\hline \multirow[t]{2}{*}{ SIZE $_{t}$} & $0.338^{* * * *}$ & $0.338^{* * * *}$ & 0.220 & $0.271^{* *}$ \\
\hline & $(3.61)$ & $(3.87)$ & $(1.64)$ & $(2.19)$ \\
\hline \multirow[t]{2}{*}{$\mathrm{LEV}_{\mathrm{t}}$} & -0.693 & $-0.643^{*}$ & -1.023 & -1.087 \\
\hline & $(-1.64)$ & $(-1.81)$ & $(-1.26)$ & $(-1.64)$ \\
\hline
\end{tabular}


Article History: Received: 12 May 2021 Revised: 25 June 2021 Accepted: 22 July 2021 Publication: 31 August 2021

\begin{tabular}{|l|l|l|l|l|}
\hline ROA $_{\mathrm{t}}$ & $2.032^{* * * *}$ & $1.590^{* * *}$ & 1.204 & -0.471 \\
\hline & $(2.59)$ & $(2.47)$ & $(0.43)$ & $(-0.20)$ \\
\hline $\mathrm{MB}_{\mathrm{t}}$ & $0.251^{* * * *}$ & $0.236^{* * *}$ & -0.001 & -0.023 \\
\hline & $(2.74)$ & $(3.35)$ & $(-0.01)$ & $(-0.35)$ \\
\hline CONSTANT & $-7.641^{* * *}$ & $-7.600^{* * *}$ & -4.565 & $-5.506^{*}$ \\
\hline & $(-3.93)$ & $(-4.19)$ & $(-1.43)$ & $(-1.88)$ \\
\hline OBS & 1157 & 1157 & 466 & 466 \\
\hline $\mathrm{R}^{2}$ (WITHIN) & 0.107 & 0.101 & 0.092 & 0.110 \\
\hline
\end{tabular}

\section{ROBUSTNESS CHECKS}

This paper conducts two tests to test the robustness of research results above. In the first place, we present robustness results of adopting an alternative crash risk model. Second, the sample of the paper does not include accounting period in 2008, so as to exclude the effect of the financial crisis.

\subsection{Different Measure of Crash Risk}

Based on existing research [35-36], this paper recalculate $\mathrm{W}_{\mathrm{it}}$, and calculate crash risk based on model (2) and model (3).

Table VIII presents the result in column (1) and column (2). The coefficients on crash risk are pronounced and positive, which shows the test results are consistent with research findings above.

\subsection{Change Sample Periods}

Referring to [35], considering the effect of the 2008 financial crisis on stock market, the year sample of 2008 is excluded. Column (3) and column (4) in Table VIII presents that the coefficient on PC is pronounced, which shows that the research conclusions are robust.

TABLE VIII. Robustness checks

\begin{tabular}{|l|l|l|l|l|}
\hline \multirow{3}{*}{ VARIABLE } & $(\mathbf{1})$ & $(\mathbf{2})$ & $(\mathbf{3})$ & $(\mathbf{4})$ \\
\cline { 2 - 5 } & NCSKEW $_{\mathbf{t}+\mathbf{1}}$ & DUVOL $_{\mathbf{t}+\mathbf{1}}$ & NCSKEW $_{\mathbf{t}+\mathbf{1}}$ & DUVOL $_{\mathbf{t}+\mathbf{1}}$ \\
\hline PC & $-0.119^{* * * *}$ & $-0.100^{* * * *}$ & $-0.229^{* * * *}$ & $-0.201^{* * *}$ \\
\hline & $(-4.61)$ & $(-5.16)$ & $(-5.49)$ & $(-6.07)$ \\
\hline
\end{tabular}


Article History: Received: 12 May 2021 Revised: 25 June 2021 Accepted: 22 July 2021 Publication: 31 August 2021

\begin{tabular}{|c|c|c|c|c|}
\hline NCSKEW $_{\mathrm{t}}$ & $-0.129^{* * * *}$ & & $-0.075 * * *$ & \\
\hline & $(-9.74)$ & & $(-4.55)$ & \\
\hline \multirow[t]{2}{*}{$\mathrm{DUVOL}_{\mathrm{t}}$} & & $-0.140 * * *$ & & $-0.053^{3}$ \\
\hline & & $(-11.53)$ & & $(-2.87)$ \\
\hline \multirow[t]{2}{*}{$\mathrm{RET}_{\mathrm{t}}$} & $1.017^{* *}$ & $0.788^{* *}$ & $0.055^{* *}$ & $0.060^{* * * *}$ \\
\hline & (2.35) & (2.44) & (2.47) & $(2.86)$ \\
\hline \multirow[t]{2}{*}{ SIGMA $_{t}$} & 1.332 & 0.685 & 0.006 & -0.239 \\
\hline & $(0.62)$ & $(0.43)$ & $(0.01)$ & $(-0.34)$ \\
\hline \multirow[t]{2}{*}{ TURNOVER $_{t}$} & $0.141^{* * * *}$ & $0.110^{\text {***** }}$ & 0.026 & 0.023 \\
\hline & (7.41) & $(7.64)$ & $(0.75)$ & $(0.83)$ \\
\hline \multirow[t]{2}{*}{$\mathrm{SIZE}_{\mathrm{t}}$} & $-0.071^{* * * *}$ & $-0.041^{* * * *}$ & $0.106^{* * *}$ & $0.142^{* * * *}$ \\
\hline & $(-4.06)$ & $(-3.04)$ & $(4.04)$ & $(6.81)$ \\
\hline \multirow[t]{2}{*}{$\mathrm{LEV}_{\mathrm{T}}$} & -0.005 & 0.022 & $-0.548^{* * *}$ & $-0.480^{* * * * * *}$ \\
\hline & $(-0.06)$ & $(0.31)$ & $(-3.83)$ & $(-4.25)$ \\
\hline \multirow[t]{2}{*}{$\mathrm{ROA}_{\mathrm{t}}$} & $0.773^{* * * *}$ & $0.545^{* * * *}$ & -0.092 & -0.144 \\
\hline & $(3.39)$ & $(3.08)$ & $(-0.26)$ & $(-0.49)$ \\
\hline \multirow[t]{2}{*}{$\mathrm{MB}_{\mathrm{t}}$} & $0.076^{* * *}$ & $0.051^{* * * *}$ & $0.114^{* * * *}$ & $0.098^{* * * *}$ \\
\hline & $(6.59)$ & $(6.22)$ & $(5.87)$ & $(6.43)$ \\
\hline \multirow[t]{2}{*}{ CONSTANT } & $1.231^{* * *}$ & $0.691^{* *}$ & $-2.407^{* * * *}$ & $-3.116^{* * * *}$ \\
\hline & $(3.44)$ & $(2.49)$ & $(-4.44)$ & $(-7.21)$ \\
\hline OBS & 8163 & 8163 & 7276 & 7276 \\
\hline $\mathrm{R}^{2}$ (WITHIN) & 0.049 & 0.051 & 0.028 & 0.031 \\
\hline
\end{tabular}

\section{ADDITIONAL TEST}

\subsection{The Effect of Corporate Governance}

The more concentrated shareholding structure, the easier it is for big shareholders to encroach on the economic interests of small shareholders [37]. The decision-making of enterprise manager is usually guided by the interests of big shareholders and lacks consideration of the interests of small shareholders. When the company performance declines, the major shareholders may compensate the management by increasing in-service consumption, which virtually deteriorates the business prospects of the company. In addition, Tunneling by major shareholders will distort accounting income and increase the information asymmetry between company and outside world [38]. These will lead to an increase in crash risk. Therefore, this paper predicts higher shareholding ratio of major shareholders will weaken the influence of political connections on reducing crash risk. 
To test the above prediction, this paper divides the sample into higher shareholding ratio of big shareholders and lower shareholding ratio of small shareholders based on shareholding ratio. Table IX presents that the higher shareholding ratio weakens the positive influence of political connections on reducing crash risk.

TABLE IX. The effect of corporate governance

\begin{tabular}{|c|c|c|c|c|}
\hline \multirow[t]{2}{*}{ VARIABLE } & \multicolumn{2}{|c|}{$\begin{array}{l}\text { LOWER SHAREHOLDING } \\
\text { RATIO }\end{array}$} & \multicolumn{2}{|c|}{$\begin{array}{l}\text { HIGHER SHAREHOLDING } \\
\text { RATIO }\end{array}$} \\
\hline & NCSKEW $_{t+1}$ & DUVOL $_{t+1}$ & NCSKEW $_{t+1}$ & DUVOL $_{t+1}$ \\
\hline \multirow[t]{2}{*}{$\mathrm{PC}_{\mathrm{t}}$} & $-0.419^{2 * 3 *}$ & $-0.301^{* * * *}$ & -0.054 & -0.009 \\
\hline & $(-3.20)$ & $(-2.62)$ & $(-0.46)$ & $(-0.08)$ \\
\hline \multirow[t]{2}{*}{ NCSKEW $_{t}$} & -0.106 & & $-0.261^{* * *}$ & \\
\hline & $(-1.97)$ & & $(-4.90)$ & \\
\hline \multirow[t]{2}{*}{ DUVOL $_{t}$} & & -0.052 & & $-0.290^{* * * *}$ \\
\hline & & $(-0.85)$ & & $(-5.26)$ \\
\hline \multirow[t]{2}{*}{ TURNOVER $_{\mathrm{t}}$} & 0.105 & 0.088 & 0.069 & 0.108 \\
\hline & $(0.87)$ & (1.07) & $(0.68)$ & $(1.23)$ \\
\hline \multirow[t]{2}{*}{$\mathrm{RET}_{\mathrm{t}}$} & -0.080 & -0.015 & 0.003 & 0.011 \\
\hline & $(-0.92)$ & $(-0.20)$ & $(0.04)$ & $(0.21)$ \\
\hline \multirow[t]{2}{*}{ SIGMA $_{t}$} & 0.389 & 0.694 & 4.540 & 2.107 \\
\hline & $(0.12)$ & $(0.30)$ & (1.51) & $(0.91)$ \\
\hline \multirow[t]{2}{*}{$\mathrm{SIZE}_{\mathrm{t}}$} & -0.103 & -0.032 & 0.194 & 0.205 \\
\hline & $(-0.76)$ & $(-0.31)$ & (1.08) & $(1.32)$ \\
\hline \multirow[t]{2}{*}{$\mathrm{LEV}_{\mathrm{t}}$} & -0.179 & 0.082 & 0.128 & 0.022 \\
\hline & $(-0.28)$ & $(0.17)$ & $(0.16)$ & $(0.03)$ \\
\hline \multirow[t]{2}{*}{$\mathrm{ROA}_{\mathrm{t}}$} & -0.504 & 0.129 & 1.314 & 0.960 \\
\hline & $(-0.47)$ & $(0.16)$ & (1.11) & $(0.99)$ \\
\hline \multirow[t]{2}{*}{$\mathrm{MB}_{\mathrm{t}}$} & $0.273^{* * *}$ & $0.228^{* * * *}$ & 0.102 & $0.088^{*}$ \\
\hline & $(4.08)$ & $(4.33)$ & (1.58) & $(1.85)$ \\
\hline \multirow[t]{2}{*}{ CONSTANT } & 1.522 & 0.026 & -5.133 & -5.114 \\
\hline & $(0.55)$ & $(0.01)$ & $(-1.35)$ & $(-1.57)$ \\
\hline OBS & 704 & 704 & 726 & 726 \\
\hline $\mathrm{R}^{2}$ (WITHIN) & 0.096 & 0.102 & 0.112 & 0.136 \\
\hline
\end{tabular}

6.2 The Influence of Marketization 
Prior research find that if a region has a higher degree of marketization, earnings manipulation by companies in the region will be lower [39], furthermore, the lower level of earnings management, the lower crash risk [32][40]. Conversely, if a company is located in a lower marketization, earnings management will be enhanced, and crash risk can increase. Therefore, if the degree of marketization in a region is higher, the weakening influence of political links on crash risk will be reduced.

To test the above prediction, we divide the sample into regions with a higher marketization and regions with a lower marketization based on marketization index [41]. Table $\mathrm{X}$ reveals that in regions where marketization degree is lower, the negative correlation between political link and crash risk is more pronounced.

TABLE X. The effect of marketization

\begin{tabular}{|c|c|c|c|c|}
\hline \multirow[t]{2}{*}{ VARIABLE } & \multicolumn{2}{|c|}{$\begin{array}{l}\text { LOWER DEGREE } \\
\text { MARKETIZATION }\end{array}$} & \multicolumn{2}{|c|}{$\begin{array}{l}\text { HIGHER DEGREE } \\
\text { MARKETIZATION }\end{array}$} \\
\hline & NCSKEW $_{t+1}$ & DUVOL $_{t+1}$ & NCSKEW $_{t+1}$ & DUVOL $_{t+1}$ \\
\hline \multirow[t]{2}{*}{$\mathrm{PC}_{\mathrm{t}}$} & $-0.273^{* *}$ & $-0.231^{* *}$ & -0.482 & -0.188 \\
\hline & $(-2.48)$ & $(-2.58)$ & $(-0.85)$ & $(-0.51)$ \\
\hline \multirow[t]{2}{*}{ NCSKEW $_{\mathrm{t}}$} & -0.055 & & $-0.558^{* * * *}$ & \\
\hline & $(-1.08)$ & & $(-3.84)$ & \\
\hline \multirow[t]{2}{*}{ DUVOL $_{t}$} & & -0.005 & & $-0.568^{* * * *}$ \\
\hline & & $(-0.08)$ & & $(-3.50)$ \\
\hline \multirow[t]{2}{*}{ TURNOVER $_{\mathrm{t}}$} & 0.121 & $0.117^{*}$ & -0.402 & -0.421 \\
\hline & $(1.49)$ & $(1.78)$ & $(-1.05)$ & $(-1.49)$ \\
\hline \multirow[t]{2}{*}{$\mathrm{RET}_{\mathrm{t}}$} & $0.152^{* *}$ & $0.171^{* * *}$ & $-0.782^{* *}$ & $-0.676^{* * * *}$ \\
\hline & $(2.30)$ & $(2.68)$ & $(-2.78)$ & $(-3.07)$ \\
\hline \multirow[t]{2}{*}{ SIGMA $_{t}$} & $-6.375^{* * *}$ & $-5.001^{* * * *}$ & $24.123^{* *}$ & $22.431^{* * * *}$ \\
\hline & $(-2.98)$ & $(-2.90)$ & (2.36) & $(2.87)$ \\
\hline \multirow[t]{2}{*}{$\mathrm{SIZE}_{\mathrm{t}}$} & -0.019 & 0.016 & $-0.651^{*}$ & $-0.611^{* * *}$ \\
\hline & $(-0.30)$ & $(0.31)$ & $(-1.71)$ & $(-2.39)$ \\
\hline \multirow[t]{2}{*}{$\mathrm{LEV}_{\mathrm{t}}$} & -0.188 & -0.110 & 2.779 & 2.359 \\
\hline & $(-0.44)$ & $(-0.33)$ & (1.54) & $(1.42)$ \\
\hline \multirow[t]{2}{*}{$\mathrm{ROA}_{\mathrm{t}}$} & $-2.279^{* * * * *}$ & $-1.966^{* * * * *}$ & $8.557^{* * 1}$ & $5.562^{* * * *}$ \\
\hline & $(-3.15)$ & $(-3.29)$ & $(4.24)$ & $(3.79)$ \\
\hline $\mathrm{MB}_{\mathrm{t}}$ & $0.173^{\text {****4 }}$ & $0.138^{* * * *}$ & 0.775 & $0.772^{*}$ \\
\hline
\end{tabular}


Article History: Received: 12 May 2021 Revised: 25 June 2021 Accepted: 22 July 2021 Publication: 31 August 2021

\begin{tabular}{|l|l|l|l|l|}
\hline & $(3.40)$ & $(3.38)$ & $(1.50)$ & $(1.97)$ \\
\hline CONSTANT & 0.476 & -0.289 & 9.849 & $9.569^{*}$ \\
\hline & $(0.36)$ & $(-0.27)$ & $(1.18)$ & $(1.77)$ \\
\hline OBS & 901 & 901 & 218 & 218 \\
\hline $\mathrm{R}^{2}($ WITHIN $)$ & 0.062 & 0.064 & 0.032 & 0.035 \\
\hline
\end{tabular}

\subsection{The Influence of Ownership}

Compared with other types of enterprises, in foreign funded enterprises, corporate governance is relatively strict, accounting information transparency is higher, and information asymmetry between the firm and the outside world is lower. Therefore, this paper predicts that in foreign funded firms, the influence of political link in reducing crash risk will be weaker.

To test the above prediction, firstly, we introduce a dummy variable. If it belongs to a foreign-funded enterprise, the dummy variable is defined as 1 , otherwise 0 , and we test the effect of ownership. Table XI presents that political link has a bigger effect on the crash risk in non- foreign funded firm than that of foreign funded firm.

\section{TABLE XI. The effect of ownership}

\begin{tabular}{|c|c|c|c|c|}
\hline \multirow[t]{2}{*}{ VARIABLE } & \multicolumn{2}{|c|}{$\begin{array}{l}\text { FOREIGN-FUNDED } \\
\text { ENTERPRISE }\end{array}$} & \multicolumn{2}{|c|}{$\begin{array}{l}\text { NON FOREIGN-FUNDED } \\
\text { ENTERPRISE }\end{array}$} \\
\hline & NCSKEW $_{t+1}$ & DUVOL $_{t+1}$ & NCSKEW $_{t+1}$ & DUVOL $_{t+1}$ \\
\hline \multirow[t]{2}{*}{$\mathrm{PC}_{\mathrm{t}}$} & -0.047 & -0.087 & $-0.215^{* * * *}$ & $-0.194^{* * * *}$ \\
\hline & $(-0.18)$ & $(-0.34)$ & $(-5.68)$ & $(-6.14)$ \\
\hline \multirow[t]{2}{*}{ NCSKEW $_{t}$} & $-0.193^{*}$ & & $-0.099^{* * * ;}$ & \\
\hline & $(-1.83)$ & & $(-5.80)$ & \\
\hline \multirow[t]{2}{*}{ DUVOL $_{t}$} & & -0.021 & & $-0.083^{* * * *}$ \\
\hline & & $(-0.16)$ & & $(-4.39)$ \\
\hline \multirow[t]{2}{*}{ TURNOVER $_{\mathrm{t}}$} & 0.027 & 0.042 & $0.109^{* * * *}$ & $0.084^{* * * *}$ \\
\hline & $(0.17)$ & $(0.38)$ & $(3.81)$ & (3.66) \\
\hline \multirow[t]{2}{*}{$\mathrm{RET}_{\mathrm{t}}$} & 0.121 & $0.271^{* * *}$ & $0.053^{* *}$ & $0.066^{* * * *}$ \\
\hline & $(1.01)$ & $(2.31)$ & (2.54) & $(3.30)$ \\
\hline \multirow[t]{2}{*}{ SIGMA $_{t}$} & -1.388 & -3.233 & -0.656 & -0.569 \\
\hline & $(-0.33)$ & $(-0.97)$ & $(-0.83)$ & $(-0.88)$ \\
\hline \multirow[t]{2}{*}{ SIZE $_{t}$} & -0.110 & -0.038 & $0.117^{* * * *}$ & $0.152^{* * *}$ \\
\hline & $(-0.51)$ & $(-0.25)$ & $(4.08)$ & $(6.54)$ \\
\hline
\end{tabular}




\begin{tabular}{|l|l|l|l|l|}
\hline LEV $_{\mathrm{t}}$ & 0.454 & -0.565 & $-0.611^{* * * *}$ & $-0.545^{* * *}$ \\
\hline & $(0.45)$ & $(-0.72)$ & $(-4.04)$ & $(-4.48)$ \\
\hline ROA $_{\mathrm{t}}$ & 2.317 & 0.689 & $0.692^{*}$ & $0.494^{*}$ \\
\hline & $(1.16)$ & $(0.35)$ & $(1.96)$ & $(1.73)$ \\
\hline $\mathrm{MB}_{\mathrm{t}}$ & $0.140^{* *}$ & $0.148^{* * *}$ & $0.138^{* * * *}$ & $0.110^{* * *}$ \\
\hline & $(2.46)$ & $(3.06)$ & $(8.34)$ & $(8.24)$ \\
\hline CONSTANT & 1.686 & 0.829 & $-2.706^{* * *}$ & $-3.358^{* * *}$ \\
\hline & $(0.38)$ & $(0.27)$ & $(-4.57)$ & $(-7.01)$ \\
\hline OBS & 237 & 237 & 6921 & 6921 \\
\hline $\mathrm{R}^{2}$ (WITHIN) & 0.120 & 0.150 & 0.054 & 0.058 \\
\hline
\end{tabular}

\section{CONCLUSIONS}

This paper tests the effect of political connections on the risk of stock price crash. The results of the study show that: political connections of enterprise may help reduce crash risk. In companies with lower proportion of major shareholders, lower marketization, and in nonforeign-funded enterprises, political links and crash risk are significantly negative correlation. This study tests the endogeneity of political connections by Heckman model, propensity matching score model (PSM), different methods to measure crash risk, and different sample period, the conclusions remain unchanged.

The enlightenment value of the research as follows: firstly, we should exert the positive influence of political connections, improve accounting conservatism and reduce information asymmetry; Secondly, to reduce the shareholding ratio of major shareholders, which will help reduce the probability of major shareholders deliberately hide bad news; Finally, it is necessary to accelerate the process of marketization, strengthen corporate governance of non-foreignfunded enterprise, and will reduce stock price crash risk, which will help steady operation of China's capital market. In addition, the research conclusion also has certain reference significance for other emerging market countries.

\section{ACKNOWLEDGEMENTS}

This research was supported by Top-notch Talents Project of Higher Education Institutions in Anhui Province of China (Grant No.GXFX2017104), Humanities and Social Science Research Project of Higher Education Institutions in Anhui Province of China (Grant No.SK2020A0448)

\section{REFERENCE}


[1] Chaney, PK, Faccio M, Parsley D (2011) The quality of acounting information in politically connected firms. Journal of Accounting \& Economics 51(1-2): 58-76

[2] Chen CJP, Ding Y, Kim C (2010) High-Level Politically Connected Firms, Corruption, and Analyst Forecast Accuracy around the World. Journal of International Business Studies 41(9): 1505-1524

[3] Shen H, Yang Y, Pan F (2014) Political connections, securities violations and earnings quality of private listed companies. Finance Research 01: 194-206

[4] Ferguson T, Voth HJ (2008) Betting on Hitler - the value of political connections in Nazi Germany. Quarterly Journal of Economics 123(1): 101-137

[5] Johnson S, Mitton T (2003) Cronyism and capital controls: evidence from Malaysia. Journal of Financial Economics 67(2): 351-382

[6] Lei G, Li S, Wang X (2009) Political connection, auditor selection and company value. Management World 07: 145-155

[7] Li H, Meng L, Wang Q, Zhou LA (2008) Political connections, financing and firm performance: evidence from chinese private firms. Journal of Development Economics,vol. 87, no. 2, pp.283-299

[8] Wu W, Wu C, Liu X (2008) The government background and corporate value of the executives of chinese private listed companies. Economic Research 07: 130-141

[9] Claessens S, Feijen E, Laeven L (2008) Political connections and preferential access to finance: the role of campaign contributions. Journal of Financial Economics 88(3): 554-580

[10] Deng J, Zeng Y (2009) Can political connections improve the operating performance of private enterprises? China Industrial Economics 02: 98-108

[11] Faccio, M. (2006) Politically connected firms. American Economic Review 96(1): 369-386

[12] Fan JPH, Wong TJ, Zhang T (2007) Politically connected CEOs, corporate governance, and post-IPO performance of china's newly partially privatized firms. Journal of Financial Economics 84(2): 330-357

[13] Lin JYF, Cai F, Li Z (1998) Competition, policy burdens, and state-owned enterprise reform. American Economic Review 88(2): 422-427

[14] Hu Y, Zhang Z (2009) The political connection of executives and company performance: based on the empirical research of state-owned power production in listed companies. China Soft Science 06: 128-137

[15] Du X, Zhou Z (2009) The level of political connection and the real performance of chinese private listed companies. Economics and Management Research 08: 37-43+49, 2009.

[16] Du X, Lei Y, Guo J (2009) Political connection and the accounting conservatism of private listed companies. China Industrial Economics 07: 87-97

[17] $\mathrm{Hu} X$ (2006) The political identity of private entrepreneurs and the financing convenience of private enterprises: taking the top 100 private enterprises in zhejiang province as an example. 
Management World 05: 107-113+141

[18] Chen Y, Zhu S (2009) Political relations, institutional environment and capital investment of listed companies. Financial Research 35(12): 27-39

[19] Zhang M, Huang J (2009) Political connection, diversification and corporate risk: empirical evidence from china's securities market. Management world 07: 156-164

[20] Khwaja AI, Mian A (2005) Do lenders favor politically connected Firms? rent provision in an emerging financial market. Quarterly Journal of Economics 120(4): 1371-1411

[21] Luo D, Zhen L (2008) Private control, political relations and corporate financing constraints: based on the empirical evidence of chinese private listed companies. Financial Research 12: 164-178

[22] Francis BB, Hasan I, Sun X (2009) Political connections and the process of going public: evidence from China. Journal of International Money and Finance28(4): 696-719

[23] Pan Y, Dai Y, Li C (2009) Political connections and government subsidies for companies in financial distress: empirical evidence from chinese companies. Nankai Management Review 12(05): 6-17

[24] Fang TY, Lin F, Lin SW, et al. (2020) The association between political connection and stock price crash risk: using financial reporting quality as a moderator. Finance Research Letters 34

[25] Piotroski JD, Wong TJ, Zhang TY (2015) Political incentives to suppress negative information:evidence from chinese listed firms. Journal of Accounting Research 53(2): 405459

[26] Li S, Cao F, Sun J et al. (2020) Executive political connections, information disclosure incentives, and stock price crash risk: evidence from chinese Non-state owned Enterprises. Emerging Markets Finance and Trade

[27] Luo JH, Gong M, Lin Y et al. (2016) Political connections and stock price crash risk: evidence from China. Economics Letters 147: pp.90-92

[28] Fisman R (2001) Estimating the value of political connections. American Economic Review 91(4): 1095-1102

[29] Yu M, Hui Y, Pan H (2010) Political connection,rent-seeking and the effectiveness of local government financial subsidies. Economic Research 45(03): 65-77

[30] Cooper MJ, Gulen H, Ovtchinnikov AV (2010) Corporate political contributions and stock returns. Journal of Finance 65(2): 687-724

[31] Chen J, Hong H, Stein JC (2001) Forecasting crashes: trading volume, past returns, and conditional skewness in stock prices. Journal of Financial Economics 61(3): 345-381

[32] Hutton AP, Marcus AJ, Tehranian H (2009) Opaque financial reports, $\mathrm{R}^{2}$, and crash risk. Journal of Financial Economics 94(1): 67-86

[33] Xu N, Jiang X, Yi Z et al. (2013) Does political connection affect the efficiency of law enforcement of investor legal protection? Economics (Quarterly) 12(02): 373-406 
[34] Kim JB, Wang Z, Zhang L (2016) CEO overconfidence and stock price crash risk. Contemporary Accounting Research 33(4): 1720-1749

[35] Kong D, Shi L, Zhang F (2021) Explain or conceal? causal language intensity in annual report and stock price crash risk. Economic Modelling 94: 715-725

[36] Kim C, Wang K, Zhang L (2019) Readability of 10-K reports and stock price crash risk. Contemporary Accounting Research 36(2): 1184-216

[37] Djankov S, La Porta R, Lopez-de-Silanes F et al. (2008) The law and economics of selfdealing. Journal of Financial Economics 88(3): 430-465

[38] Bertrand M, Mehta P, Mullainathan S (2002) Ferreting out tunneling: an application to Indian business groups. Quarterly Journal of Economics 117(1): 121-148

[39] Li Y, Che K, Yao H et al. (2012) Research on the relationship between external governance environment and earnings management based on the perspective of regional differencesalso on the substitution and protection of corporate governance. Nankai Management Review 15(04): 89-100

[40] Shi X, Hu Q, Xu F (2014) Marketization process, accounting information quality and stock price collapse risk. Journal of Zhongnan University of Economics and Law 04: 80-87+96

[41] Wang X, Fan G, Yu J (2017) China's Marketization Index Report by Province. Social Science Literature Press 